\title{
Effect of various biological control agents (BCAs) on drought resistance and spring barley productivity
}

\author{
Radik Safin*, Lilia Karimova, Lubov Nizhegorodtseva, Daria Stepankova, Gulnaz Shaimullina, and Ruslan Nazarov \\ Center for Agroecological Research, Kazan State Agrarian University, 420015 Kazan, Russia
}

\begin{abstract}
The aim of the article is to study the effect of various biological agents of biofungicides on plant resistance to drought and formation of spring barley crops. Endophytic bacteria (Bacillus subtilis), rhizospheric bacteria (Pseudomonas fluorescens), actinomycetes (Streptomyces sp.), and micromycetes (Trichoderma viride) were used as bioagents of biofungicides. Preparations based on biological agents were used to treat spring barley seeds. The studies were carried out in laboratory and field conditions. In the conditions of the model artificial acute drought, it was found that seed treatment with Streptomyces $s p$. Stimulates the leaf and root growth, as well as increases peroxidase activity in the leaves. The maximum content of proline was during seed treatment with Pseudomonas fluorescens. An increase in the content of chlorophyll was observed when treating with Trichoderma viride seeds. In the field conditions, Pseudomonas putida and Streptomyces were more efficient by the content of proline in seedlings. In terms of the spring barley yield, seed treatment with Streptomyces sp., Pseudomonas putida and Bacillus subtilis was more efficient. Streptomyces sp., Pseudomonas putida and Bacillus subtilis are promising for increasing barley resistance to drought.
\end{abstract}

\section{Introduction}

Barley is one of the main crops in the world and in the Russian Federation. Among the factors that negatively affect crop productivity, one can mention abiotic stresses, including drought [1]. Given global climatic changes, the development of methods for increasing plant resistance to drought is important [2].

In protecting plants from various stresses, biological control methods are becoming important [3]. The main direction in the biological protection of plants is the use of biological products based on various biological agents (biological control agents (BCAs)) [4].

The use of microorganisms to increase the resistance of plants to abiotic and biotic stresses (artificial or acquired immunity) is one of the most promising areas for the integrated plant protection [5-7].

Biological agents include various groups of bacteria (Agrobacterium, Bacillus, Pseudomonas, Streptomyces, etc.) and fungi (Ampelomyces, Candida, Coniothyrium, Trichoderma, etc.) [8].

The most commonly used biological agents of biofungicides are endophytic bacteria, rhizospheric bacteria (Plant Growth Promoting Rhizobacteria PGPR), actinomycetes and micromycetes of the genus Trichoderma [9-11].

The mechanisms of inducing stress resistance under the influence of biological control agents (BCAs) are associated with induced systemic resistance (ISR) and systemic acquired resistance (SAR). Thus, salicylic acid
(SA) is one of the main mechanisms of SAR in plants under the influence of Trichoderma harzianum [12]. Elicitors in the initiation of stress resistance reactions under the influence of biological agents in bacteria are liposaccharides, siderophores, flagella or flagellin, volatile compounds, salicides, the cyclic protein syringolin, antibiotics [13].

For Trichoderma, $22 \mathrm{kDa}$ xylonase, $18 \mathrm{kDa}$ serine proteinase, and others act as elicitors [14]. The use of various biological products based on biological control agents decreases the development of various diseases and increases the yield of various crops, including spring barley [15-17].

Accumulation of proline amino acids in cells [18, 19] and an increase in the activity of various oxidases, including peroxidase [20, 21], are mechanisms of increasing plant resistance to stresses.

The effect of seed treatment with biologicals on increasing yields and quality characteristics of production was described in a number of studies [22, 23].

The aim is to study the effect of various biological control agents on the drought resistance of spring barley and its productivity.

\section{Materials and methods}

The studies were conducted on the basis of the agroecological center of Kazan State Agrarian University.

\footnotetext{
Corresponding author: radiksaf2@mail.ru
} 
The object was spring barley (Hordeum vulgare subsp. Distichon), Raushan variety.

Strains from the collection of Kazan State Agrarian University were studied as biological control agents. 1. endophytic bacterium Bacillus subtilis RECB - 95 B; 2. rhizospheric bacterium Pseudomonas putida RECB - 14 B. 3. rhizospheric bacterium Pseudomonas fluorescens RECB - 44 B. 4. actinomycetes Streptomyces sp. RECB - 31 B. 5. micromycete Trichoderma viride RECB - 74 B.

The seeds of spring barley were treated with biological agents at the rate of $1.01 / \mathrm{t}$. The control seeds were treated with sterile distilled water.

Laboratory experiments were carried out using a sand culture. For experiments, vessels of a volume of 51 . were used. $3.05 \mathrm{~kg}$ of large sterile river sand was laid out in each vessel, moistening it with Knop's solution to $25 \%$ humidity to create artificial drought. The seeds were planted to a depth of $1.5-2 \mathrm{~cm}, 35$ seeds per vessel. Plants were grown under artificial lighting (a 16 hour period). All experiments were conducted in three biological replicates.

Field experiments were conducted on a plot near Kazan in 2018. In May and June 2018, there were weak arid phenomena. The soil of the experimental plots was gray forest (luvisols). The seeding rate was $500 \mathrm{pcs} / \mathrm{m} 2$. The yield of spring barley was determined by all options and was converted to grain moisture at $14 \%$. The plot area was $1.0 \mathrm{~m} 2$. The experiments were conducyed in 6 replicates.

The content of free proline in the leaves was determined by the method of Bates et al. [24] with minor modifications. A sample of $200 \mathrm{mg}$ of plant tissue was poured with $5 \mathrm{ml}$ of boiling distilled water and kept for 10 minutes in a water bath at a temperature of $100^{\circ} \mathrm{C}$. Then, $2 \mathrm{ml}$ of glacial acetic acid, $2 \mathrm{ml}$ of ninhydrin reagent were poured into a clean tube and $2 \mathrm{ml}$ of the prepared extract was added.

Samples were incubated for $20 \mathrm{~min}$ in a water bath at a temperature of $100{ }^{\circ} \mathrm{C}$, and quickly cooled up to a room temperature. After artificial cooling (cold water or ice), the optical density of the reaction products was measured at a wavelength of $520 \mathrm{~nm}$ using a SPECTROstar spectrophotometer (Germany).

The colorimetric method was used to determine the activity of the peroxidase enzyme in leaves [25].

The chlorophyll extraction was carried out with ethanol; the content was determined spectrophotometrically [26]. $0.5 \mathrm{~g}$ of fresh plant leaves were homogenized in a tissue homogenizer. The mixture was centrifuged at $10,000 \mathrm{rpm}$ for 15 minutes at $4{ }^{\circ} \mathrm{C}$. The supernatant was separated and $0.5 \mathrm{ml}$ was mixed with $4.5 \mathrm{ml}$ of $95 \%$ ethanol.

The mixture was analyzed for chlorophyll content using a SPECTROstar spectrophotometer (Germany).

To assess the significance of the difference for the mean values, the standard deviation was determined and Student's t-test was used $(\mathrm{P}<0.05)$.

\section{Results and discussion}

In the laboratory experiments, on the 21 st day after sowing, the dry mass of roots and leaves, as well as the ratio of their masses, was determined.

Table 1. Dry mass of leaves and roots of spring barley on the 28th day after sowing (laboratory experiment)

\begin{tabular}{|c|c|c|c|}
\hline Option & $\begin{array}{l}\text { Leaf } \\
\text { mass, } \\
\text { g/plant }\end{array}$ & $\begin{array}{l}\text { The } \\
\text { mass of } \\
\text { roots, } \\
\text { g/plant }\end{array}$ & $\begin{array}{c}\text { The ratio } \\
\text { of leaf } \\
\text { mass: } \\
\text { mass of } \\
\text { roots }\end{array}$ \\
\hline control & $\begin{array}{c}0.239 \\
\pm 0.012\end{array}$ & $\begin{array}{c}0.0118 \pm \\
0.0054\end{array}$ & $20.3: 1$ \\
\hline $\begin{array}{l}\text { Bacillus subtilis } \\
\text { RECB - 95 B }\end{array}$ & $\begin{array}{l}0.2867 \\
\pm 0.014\end{array}$ & $0.0114 \pm$ & $25.1: 1$ \\
\hline $\begin{array}{l}\text { Pseudomonas } \\
\text { putida } \mathrm{RECB}-14 \mathrm{~B}\end{array}$ & $\begin{array}{l}0.2639 \\
\pm 0.019\end{array}$ & $\begin{array}{c}0.0045 \pm \\
0.0004\end{array}$ & $58.6: 1$ \\
\hline $\begin{array}{l}\text { Pseudomonas } \\
\text { fluorescens RECB - } \\
44 \mathrm{~B}\end{array}$ & $\begin{array}{l}0.2775 \\
\pm 0.011 \\
\end{array}$ & $\begin{array}{c}0.0047 \pm \\
0.0002\end{array}$ & $59.0: 1$ \\
\hline $\begin{array}{l}\text { Streptomyces } \\
\text { RECB }-31\end{array}$ & $\begin{array}{l}0.4183 \\
\pm 0.022\end{array}$ & $\begin{array}{c}0.0295 \pm \\
0.0071\end{array}$ & $14.2: 1$ \\
\hline $\begin{array}{l}\text { Trichoderma viride } \\
\text { RECB - } 74 \text { B. }\end{array}$ & $\begin{array}{l}0.3835 \\
\pm 0.015\end{array}$ & $\begin{array}{c}0.0051 \pm \\
0.0004 \\
\end{array}$ & $75.2: 1$ \\
\hline
\end{tabular}

Under the conditions of model drought, the effect of the biological agents on the growth of leaves and roots was different. Bacillus subtilis RECB - 95 had no effect on these indicators and the ratio of leaf mass to root mass was close to the control one. The rhizospheric bacteria Pseudomonas putida RECB - 14 B and Pseudomonas fluorescens RECB - $44 \mathrm{~B}$, as well as Trichoderma viride RECB - 74 B stimulated leaf growth, but inhibited root growth. The highest indicators of mass and leaves and roots were when treating with Streptomyces spp. RECB - 31, and their ratio was minimal. The results are shown in Table 2.

Table 2. The content of proline in the leaves $(\mathrm{mg} / \mathrm{kg})$ and peroxidase activity (laboratory experiment)

\begin{tabular}{|c|c|c|}
\hline Option & \begin{tabular}{|c|} 
content of \\
proline in \\
leaves*, $\mathrm{mg} / \mathrm{kg}$
\end{tabular} & $\begin{array}{c}\text { activity of } \\
\text { peroxidase in } \\
\text { leaves** }\end{array}$ \\
\hline The control & $25.821 \pm 0.366$ & $0.890 \pm 0.027$ \\
\hline $\begin{array}{l}\text { Bacillus subtilis RECB } \\
-95 \mathrm{~B}\end{array}$ & $23.406 \pm 0.132$ & $2.458 \pm 0.012$ \\
\hline $\begin{array}{l}\text { Pseudomonas putida } \\
\text { RECB }-14 \mathrm{~B}\end{array}$ & $18.156 \pm 0.279$ & $1.185 \pm 0.010$ \\
\hline $\begin{array}{l}\text { Pseudomonas } \\
\text { fluorescens RECB }-44 \\
\text { B }\end{array}$ & $33.615 \pm 0.279$ & $1.470 \pm 0.026$ \\
\hline $\begin{array}{l}\text { Streptomyces } \\
\text { RECB }-31\end{array}$ & $21.618 \pm 0.171$ & $2.826 \pm 0.102$ \\
\hline $\begin{array}{ll}\text { Trichoderma } & \text { viride } \\
\text { RECB }-74 \text { B. } & \\
\end{array}$ & $24.597 \pm 0.139$ & $1.662 \pm 0.039$ \\
\hline
\end{tabular}


An increase in the proline content in spring barley leaves was observed when treating with Pseudomonas fluorescens RECB - 44 B. For other strains, the proline content was below the control one.

The maximum activity of peroxidase in the leaves was observed for Bacillus subtilis RECB - 95 B and Streptomyces sp. RECB - 31, but in other embodiments, an increase in enzyme activity was observed.

Table 3. The content of chlorophyll (mg/g wet weight) in the leaves of spring barley on the 28th day of the experiment (laboratory experiment)

\begin{tabular}{|l|l|l|l|}
\hline \multicolumn{1}{|c|}{ Option } & Chlorophyll a & Chlorophyll b & Ratio a/b \\
\hline control & $1.168 \pm 0.016$ & $0.558 \pm 0.042$ & 2.093 \\
\hline $\begin{array}{l}\text { Bacillus subtilis } \\
\text { RECB - 95 B }\end{array}$ & $0.783 \pm 0.055$ & $0.350 \pm 0.026$ & 2.236 \\
\hline $\begin{array}{l}\text { Pseudomonas } \\
\text { putida RECB } \\
\text { 14 B }\end{array}$ & $0.687 \pm 0.038$ & $0.277 \pm 0.014$ & 2.483 \\
\hline $\begin{array}{l}\text { Pseudomonas } \\
\text { fluorescens } \\
\text { RECB - 44 B }\end{array}$ & $0.238 \pm 0.016$ & $0.114 \pm 0.007$ & 2.084 \\
$\begin{array}{l}\text { Streptomyces } \\
\text { spp. RECB - } 31\end{array}$ & $0.817 \pm 0.044$ & $0.363 \pm 0.021$ & 2.252 \\
\hline $\begin{array}{l}\text { Trichoderma } \\
\text { viride RECB } \\
\text { 74 B. }\end{array}$ & $1.966 \pm 0.098$ & $0.930 \pm 0.047$ & 2.113 \\
\hline
\end{tabular}

An increase in the chlorophyll content in the leaves of barley plants under severe drought conditions occurred when treating seeds with Trichoderma viride RECB - 74 B. In other variants with bioagents, the chlorophyll content decreased with the exception of the variant with Pseudomonas fluorescens RECB - 44 B; the use of biological agents increased the ratio of chlorophyll a to chlorophyll b.

In the field conditions, the content of proline in the leaves of spring barley was determined during the phase of full germination (Table 3 ).

Table 4. The content of proline in the leaves $(\mathrm{mg} / \mathrm{kg})$ of spring barley in the seedling phase (field experiment)

\begin{tabular}{|l|c|c|}
\hline \multicolumn{1}{|c|}{ Option } & $\begin{array}{c}\text { The content of } \\
\text { proline in } \\
\text { leaves*, mg/kg }\end{array}$ & $\%$ \\
\hline Control & $77.71 \pm 5.31$ & 109 \\
\hline $\begin{array}{l}\text { Bacillus subtilis RECB } \\
\text { 95 B }\end{array}$ & $84.37 \pm 3.37$ & 184 \\
\hline $\begin{array}{l}\text { Pseudomonas putida } \\
\text { RECB - 14 B }\end{array}$ & $143.16 \pm 3.73$ & 117 \\
\hline $\begin{array}{l}\text { Pseudomonas } \\
\text { fluorescens RECB } \\
\text { 44 B spp. }\end{array}$ & $97.51 \pm 6.33$ & 125 \\
\hline $\begin{array}{l}\text { Streptomyces } \\
\text { RECB - 31 B viride }\end{array}$ & $44.37 \pm 1.12$ & 57 \\
\hline $\begin{array}{l}\text { Trichoderma } \\
\text { RECB - 74 B }\end{array}$ & 109 \\
\hline
\end{tabular}
$P S$

The maximum proline content was when treting with eudomonas putida RECB - 14 B and Streptomyces $s p$. RECB - 31.

In the field conditions, at the early stages of plant development (tillering) and during shooting, the highest total chlorophyll content was observed when seeds were treated with Pseudomonas fluorescens RECB - 44 B (Table 5). In the earing phase, a positive effect of seed treatment with biological agents was not observed.

Table 5. The content of total chlorophyll (mg/g per wet weight) in the leaves at different stages of development of spring barley (field experiment)

\begin{tabular}{|l|c|c|c|}
\hline \multicolumn{1}{|c|}{ Option } & Tillering & $\begin{array}{c}\text { Exit to the } \\
\text { handset }\end{array}$ & Heading \\
\hline The control & $1.136 \pm 0.058$ & $1.542 \pm 0.081$ & $2.593 \pm 0.116$ \\
\hline $\begin{array}{l}\text { Bacillus } \\
\text { subtilis RECB } \\
-95 \text { B }\end{array}$ & $1.508 \pm 0.047$ & $1.613 \pm 0.049$ & $1.778 \pm 0.053$ \\
\hline $\begin{array}{l}\text { Pseudomonas } \\
\text { putida RECB } \\
14 \text { B }\end{array}$ & $1.294 \pm 0.052$ & $1.126 \pm 0.044$ & $2.570 \pm 0.012$ \\
\hline $\begin{array}{l}\text { Pseudomonas } \\
\text { fluorescens } \\
\text { RECB - 44 B }\end{array}$ & $1.550 \pm 0.036$ & $1.752 \pm 0.044$ & $2.238 \pm 0.079$ \\
\hline $\begin{array}{l}\text { Streptomyces } \\
\text { spp. RECB } \\
\text { 31 }\end{array}$ & $1.340 \pm 0.062$ & $1.399 \pm 0.068$ & $2.415 \pm 0.096$ \\
\hline $\begin{array}{l}\text { Trichoderma } \\
\text { viride RECB } \\
\text { 74 B. }\end{array}$ & $0.768 \pm 0.016$ & $1.610 \pm 0.035$ & $1.938 \pm 0.046$ \\
\hline
\end{tabular}

In dry summers, the use of all agents for seed treatment increased the yield of spring barley in comparison with the control variant (Table 6).

Table 6. Yield (t/ha) of spring barley (field experiment)

\begin{tabular}{|l|c|c|}
\hline \multicolumn{1}{|c|}{ Option } & \multicolumn{1}{|c|}{$\begin{array}{c}\text { Yield, } \\
\text { t/ha }\end{array}$} & $\begin{array}{c}\text { Add to } \\
\text { control., } \\
\text { T/ha }\end{array}$ \\
\hline Control & $2.08 \pm 0.11$ & \\
\hline $\begin{array}{l}\text { Bacillus subtilis RECB } \\
\text { 95 B }\end{array}$ & $2.65 \pm 0.09$ & 0.57 \\
\hline $\begin{array}{l}\text { Pseudomonas putida } \\
\text { RECB - 14 B }\end{array}$ & $2.72 \pm 0.18$ & 0.64 \\
\hline $\begin{array}{l}\text { Pseudomonas } \\
\text { fluorescens RECB }-44 \\
\text { B }\end{array}$ & $2.29 \pm 0.05$ & 0.21 \\
\hline $\begin{array}{l}\text { Streptomyces spp. RECB } \\
-31 \text { B }\end{array}$ & $2.81 \pm 0.12$ & 0.73 \\
\hline $\begin{array}{l}\text { Trichoderma } \\
\text { RECB - 74 B }\end{array}$ & $2.32 \pm 0.10$ & 0.24 \\
\hline
\end{tabular}

The highest yield was observed when treating with Streptomyces spp. RECB - 31, Pseudomonas putida RECB - 14 B and Bacillus subtilis RECB - 95 B. For the variant with Streptomyces spp. RECB - 31, the yield increase was $0.73 \mathrm{t} / \mathrm{ha}$. 


\section{Conclusion}

The studies have shown that in the conditions of artificial acute drought, the effect of biological agents on the resistance of barley plants to stress is different. The use of Streptomyces spp. RECB - 31 stimulates the growth of both leaves and roots. All biological agents increase the activity of peroxidase in the leaves, but Streptomyces spp. RECB - 31 is more efficient. An increase in the content of chlorophyll in the leaves occurred when treating plants with Trichoderma viride RECB - 74 B.

In the field conditions, bacterial biological agents increased the proline content in the leaves, while Trichoderma viride RECB - $74 \mathrm{~B}$, on the contrary, significantly reduced this indicator. With the exception of Trichoderma viride RECB-74 B seed treatment, all biological agents increased the chlorophyll content at the early stages of barley development. This was especially noticeable for Pseudomonas fluorescens RECB - 44 B. In conditions of weak drought, the use of all preparations increased the yield, but the most noticeable positive effect was when treating with Streptomyces spp. RECB $31 \mathrm{~V}$.

The positive effect on peroxidase activity was observed for all agents, but there some differences between them. The results showed that the effect of various groups of biological control agents (BCAs) on the resistance of barley plants to drought has different mechanisms, which confirms the data obtained by other researchers $[26,27]$.

The differences in the effects of the strains observed in laboratory and field experiments can be associated with a different degree of drought (a strong degree in the laboratory conditions, a weak degree in the field experiments).

The differences between different microorganisms must be taken into account when developing biological methods for controlling stresses.

\section{Recommendations}

To increase the resistance of spring barley to drought and increase the yield, Streptomyces spp. RECB - $31 \mathrm{~V}$, Pseudomonas putida RECB - 14 B and Bacillus subtilis RECB - 95 B can be used.

\section{Acknowledgements}

The study was conducted with the financial support provided by the Ministry of Education and Science Of The Russian Federation (the agreement number is №14.610.21.0017. The unique identifier of the project is RFMEFI61017X0017).

\section{References}

1. S.A. Anjum, X. Xie, L. Wang, M. F. Saleem, C. Man, W. Lei, Morphological, physiological and biochemical responses of plants to drought stress
African J. of Agricultural Research 6(9), 20262032, (2011)

2. M Matiu, D.P. Ankerst, A. Menzel, Interactions between temperature and drought in global and regional crop yield variability during 1961-2014 PLoS ONE 12(5), e0178339 (2017)

3. P. Calvo, L.M. Nelson, J. Kloepper, Agricultural uses of plant biostimulants Plant Soil 383, 3-41 (2014)

4. J. M. Whipps, M. McQuilken, Biological control agents in plant disease control in Disease Control in Crops: Biological and Environmentally Friendly Approaches 27-61 (2009)

5. A. Nega, Review on concepts in biological control of plant pathogens J. of Biology, Agriculture and Healthcare 4(27), 33-54 (2014)

6. M. Grover, S. Z.Ali, V. Sandhya, A. Rasul, B.Venkateswarlu, Role of microorganisms in adaptation of agriculture crops to abiotic stress World J. Microbiol. Biotechnol. 27(5), 1231-1240 (2010)

7. X.-M. Xu, P. Jeffries, M. Pautasso, M. J. Jeger, Combined use of biocontrol agents to manage plant diseases in theory and practice Phytopathology 101, 1024-1031 (2011)

8. B. B. McSpadden, D. R. Fravel, Biological control of plant pathogens: Research, commercialization, and application in the USA Online. Plant Health Progress (2002) doi:10.1094/PHP-2002-0510-01RV.

9. J. Hallmann, A. Quadt-Hallmann, W. F. Mahaffee, J. W. Kloepper, Bacterial endophytes in agricultural crops Can. J. Microbiol. 43, 895- 914 (1997)

10. R. Mendes, P. Garbeva, J.M. Raaijmakers, The rhizosphere microbiome: significance of plant beneficial, plant pathogenic, and human pathogenic microorganisms FEMS Microbiol Rev. 37, 634-663 (2013)

11. L. Naher, U. K. Yusuf, A. Ismail, K. Hossain, Trichoderma spp.: A biocontrol agent for sustainable management of plant diseases Pak. J. Bot. 46(4), 1489-1493 (2014)

12. S. Deshmukh, R. Hueckelhoven, P. Schaefer, J. Imani, M. Sharma, The root endophytic fungus Piriformospora indica requires host cell death for proliferation during mutualistic symbiosis with barley in Proc. of National Academic Sciences USA 103, 18450-18457 (2006)

13. H. Meziane, I. van der Sluis, L.C. van Loon, M. Höfte, PAHM Bakker, Determinants of Pseudomonas putida WCS358 involved in inducing systemic resistance in plants Molecular Plant Pathology 6, 177-185 (2005)

14. S.L. Woo, F. Scala, M. Ruocco, M. Lorito, The molecular biology of the interactions between Trichoderma spp., phytopathogenic fungi, and plants Phytopathology 96, 181-185 (2006) 
15. A. Baturo, Effect of thermotherapy, grain treatment and leaf spraying with biological control agents on spring barley (Hordeum vulgare) health in organic system Phytopathol. Pol. 41, 15-26 (2006)

16. L. O. Kriuchkova, Biological control of leaf disease of barley with Bacillus strain BIOLOGIJA 63(3), 289-295 (2017)

17. M. Grzesiak, M. Filek, A. Barbasz, B. Kreczmer, H. Hartikainen, Relationships between polyamines, ethylene, osmoprotectants and antioxidant enzymes activities in wheat seedlings after short-term PEGand $\mathrm{NaCl}$-induced stresses Plant Growth Regul. 69, 177-189 (2013)

18. B Jensen, I.M.B. Knudsen, D. F. Jensen, Biological seed treatment of cereals with fresh and long-term stored formulations of Clonostachys rosea: biocontrol efficacy against Fusarium culmorum Eur. J. Plant Pathol. 106, 233-242 (2000)

19. S. Sharma, J.G. Villamon, P.E. Verslues, Essential role of tissue-specific proline synthesis and catabolism in growth and redox balance at low water potential Plant Physiol. 157, 292-304 (2011)

20. T. K. Egizbaeva, T. Lee, A. Haseyn, A. E. Halymbetova, F. Zhardemali, Cellular selection of wheat and potato using peroxidase as a marker protein drought resistance Biotechnology. Theory and practice 3, 25-32 (2010)
21. M. Almeselmani, P.S. Deshmukh, R.K. Sairam, S.R. Kushwaha, T.P. Singh, Protective role of antioxidant enzymes under high temperature stress Plant Sci. 171(3), 382-388 (2006)

22. L Philippot, J.M. Raaijmakers, P. Lemanceau, W.H. van der Putten, Going back to the roots: the microbial ecology of the rhizosphere, Nat. Rev. Microbiol. 11, 789-799 (2013)

23. L. Herrmann, D. Lesueur, Challenges in formulation and quality of biofertilisers for successful inoculation Appl. Microbiol. Biotechnol. 97, 88598873 (2013)

24. L.S. Bates, R.P. Waldrin, J.D. Ter, Rapid determination of free proline for water stress studies Plant and soil 39(1), 205-208 (1973)

25. A.N. Boyarkin, Rapid method for peroxidase activity determination Biokhimiya 16, 352-355 (1951)

26. H. K. Lichtenthaler, Chlorophylls and carotenoids: pigments of photosynthetic membranes Method Enzymol. 148, 350-382 (1987)

27. I.A. Abd El-Daim, S. Bejai, J. Meijer, Improved heat stress tolerance of wheat seedlings by bacterial seed treatment Plant and Soil 379(1-2), 337-350 (2014)

28. J. Yang, J. W. Kloepper, C.-M. Ryu, Rhizosphere bacteria help plants tolerate abiotic stress Trends Plant Sci., 14(1), 1-4 (2009) 